\title{
HISTOLOGICAL STUDIES ON THE SKIN OF THE HEAD OF SUDANESE DUCK (CAIRINA MOSCHATA) DURING POST-HATCHING PERIOD
}

\author{
MADEHA HASHIM ${ }^{1}$; AHMED H.S. HASSAN ${ }^{2}$; DOAA M. MOKHTAR ${ }^{3}$; HANAN \\ H. ABD-ELHAFEEZ ${ }^{4}$ AND NADA ABDELLAH ${ }^{5}$ \\ ${ }^{1,5}$ Histology Department, Faculty of Veterinary Medicine, Sohag University, Sohag, Egypt \\ 2,3,4 Department of Anatomy and Histology, Faculty of Veterinary Medicine, Assiut University, \\ Assiut, Egypt
}

Received: 31 August 2020; Accepted: 27 September 2020

\begin{abstract}
The integumentary system of birds is quite different from that of mammals. The current study was applied on the skin covering the head of sudanese duck (cairina moschata) from hatching day until the skin became mature. In all different ages. The skin is composed of epidermis, dermis and subcutes. The epidermis consists of stratum cornium and stratum germinitivum. The later is formed of stratum basal, stratum intermedium and stratum transivitium. The dermis is divided into stratum superficiale, stratum compactum, stratum laxum and lamina elastic. The skin of Sudanese duck was as any bird, characterized by feathers which generate from dermal papilla. The dermal papilla with the epidermal collar formed the blastema which found at early age, particularly at hatching day. Feather follicle was completely mature at two months. The completely formed feather was pushed by the new formed feather through the same dermal papilla. The maturity of the skin of head region is mainly associated with the maturity of the head feathers.
\end{abstract}

Keywords: head, cairina moscata, feather, epidermis, dermis

\section{INTRODUCTION}

Ducks are considered the second common strains of poultry in the world. In Egypt, more attention is focused lately on increasing meat production, particularly ducks which are considered the easiest domestic poultry (El-Soukkary et al., 2005).

Corresponding author: MADEHA HASHIM

E-mail address: vet_madeha@yahoo.com

Present address: Histology Department, Faculty of Veterinary Medicine, Sohag University, Sohag, Egypt
Sudanese breed is considered a local breed and more favorable to the egyptian consumer and more heat tolerant as compared to Muscovy duck (foreign breed) (Teguia et al., 2008). Bird skin is marked out by some specific morphological and physiological features. It doesn't have any sudorific glands, it is thin, elastic and its epidermis is both keratinized and lipogenic. Bird skin also acts as a sebaceous secretory organ (Stettenheim, 2000). The epidermis, the most superficial layer of the skin, is thinner in birds than in mammals (Spearman, 1966). The epidermis has two 
main layers - a superficial stratum corneum and a deeper stratum germinativium. The stratum corneum consists of flattened, keratinized cells (Elias and Menon, 1991). The dermis is thicker than the epidermis and contains blood vessels, fat deposits, nerves and free nerve endings, several types of neuroreceptors, and smooth muscles that move the feathers (Lucas and Stettenheim, 1972).

Feathers are the most characteristic feature of birds, being complex epidermal structures (Lucas and Stettenheim, 1972).

The chick epidermis was variable over different body regions; however, the comparable layers consisted of morphologically identical cells. It was consisted of 4 to 6 layers of nucleated cells and 15 to 20 layers of horny cells (Matoltsy, 1969). In the head portion of ostrich skin, there was clear separation between the epidermis and dermis. In most of the body surface, the epidermal layers were very thin. The stratum germinativum consisted of cuboidal and an polyhedral or granular cells. The following layer was flattened and very similar to chondrocyte. Externally, the stratum corneum consisted of several keratinized cells (Foroogh et al., 2013). The current study investigates the histology, histochemical, transmission and scanning electron microscopic studies as well as histomorphometrical measurements were carried out on the skin of the head region of Sudanese ducks (Cairina moschata) during the post-hatching period till maturity.

\section{MATERIALS AND METHODS}

\section{Sample collection:}

For the current study, speccimens from the skin of the head of 15 healthy Sudanese duck (Cairina moschata) after being slaughtered, were collected from farm in
Sohage city. The samples were excised from the skin covering the head regions at different ages as follows; hatching day, one week, one month, two months, and three months. All samples were in a good healthy condition. Then the samples were immediately processed for histological examination.

\section{Histological examination}

Samples were fixed in Bouin's solution for 12 hours in the fridge. Samples were extensively washed in $70 \%$ ethanol and were dehydrated in a series of ascending grade of alcohol, cleared in xylene, embedded in paraffin and finally the paraffin blocks were sectioned at $5 \mu \mathrm{m}$ thickness using sliding microtome. The sections were then stained by the following stains:

- Haematoxylin and Eosin for general histological examination.

- Periodic Acid-Schiff (PAS) for identification of neutral mucopolysaccharides.

- Crossman's trichrome stain for identification of collageneous fibers

- Weigert's Elastica for identification of elastic fibers.

- Grimlius Sliver nitrate impregnation for neuroendocrine cell and nerve fibers.

- All stain techniques were cited by Bancroft and Layton (2013). The stained sections were examined using a Leitz Dialux 20 Microscope. Photos were taken using a Canon digital camera (Candison Power shot A95).

Specimens of the skin were used for the transmission electron microscopy. Small pieces 2.0-3.0 $\mathrm{mm}$ long were placed on $2.5 \%$ cold glutraldehyde in phosphate 
buffer (PH 7.2) for 24 hours. The pieces were washed twice in $0.1 \mathrm{M}$ phosphate buffer and then post-fixed in $1 \%$ osmium tetraoxide, in the same buffer. The postfixed pieces were dehydrated in graded

\section{RESULTS}

\section{I- Light microscopy:}

\section{1- Day of hatching:}

The skin of this region was formed of three parts: the epidermis, dermis and subcutis (Fig. 1A).

\section{The epidermis:}

It is formed of two layers, stratum corneum toward the surface and stratum germinativum toward the dermis. Stratum germinativum was formed of: A-stratum basal, which was the basal layer of stratum germinativum and consisted of flat cells with flat large nuclei. B- stratum intermedium, which was formed of 1- 3 layers of poly hedral cells. C- stratum transitivum, it was the superfacial layer of stratum germinativum and formed of flattened cells, that appeared dark near to the stratum corneum. The lipid droplets were observed in the cells of the st. basal, st. intermedium and increased in the st. transivitum near to st. cornium (Fig. 1).

\section{The dermis:}

The dermis was composed of thin superficial and broad deep layers, the deep layer (stratum profundum) being further divided into an upper dense (stratum compactum) and lower looser layer (stratum luxum) (Fig. 2). Both st. superfacial and st. copactum were formed of dense regular collagenous c.t, separated from each other by avascular layer (Fig. 2). The st. luxum contained adipose tissue, large blood vessels, lymphatics, nerves, smooth muscle fibers and the base of feathers follicle (Fig. 2\& 3). The arteriovenous anastomosis, which was characterized by direct connection of thick alcohols and embedded in araldite resin. Semithin sections ( $1 \mu \mathrm{m}$ thickness) were stained with $1 \%$ toluidine blue and examined by light microscope.

- walled artery and thin - walled vein, was also demonstrated in st.luxum (Fig. 3).

\section{The feathers}

Feathers were generated from the feather follicles, which were lied completely in st.luxum of dermis. The feather follicles were formed of:

At the beginning, the epidermal cells were thickened above the condensed dermal fibroblast cells, forming placode (Fig. 4A). The placode grew downward, forming the feather bud (Fig. 4B), then the cells of feather bud were elongated by successive proliferation forming feather bulge (Fig. $4 \mathrm{C})$. The base of the bulge was evaginated to envelop the condensed dermal cells forming the dermal papilla (Fig. 4D). The dermal papilla was formed of specialized fibroblast, osteoblast and fat cells surrounded with thin epidermal layer (Fig. 4E). The epidermal tissue above the dermal papilla, was invaginated in the dermis, forming the feather follicle wall (Fig. 4F), which was formed of thick epidermal layer, covered by a thin dermal connective tissue. The epidermal layer of feather follicle wall was formed of thick germinative layers and was covered by thin corneal layer (Fig. 5). A follicular cavity was observed between the cornous layer covering the dermal papilla and cornous layer of the follicular wall (Fig. 5). The epidermal layer of the papilla was continuous with the epidermis of the follicular wall and was called the epidermal collar (Fig. 4F).

The dermal papilla and the epidermal collar formed the blastema in which the new feather will be developed (Fig. 4). Then the dermal papilla in blastema was 
elongated forming basal portion with rounded cells and an apical portion with flattened cells (Fig. 5).

The most interesting feature in this work was an important structure beside the feather follicle, which had cross sectional appearance like of an onion, this structure was called Herbst corpuscles. Not all feathers had Herbst corpuscle, while two Herbst corpuscles beside the feather follicle may be demonstrated (Fig. 6). The Herbst corpuscle was formed of axial nerve ending surrounded with inner bulb, which formed of lamellar cells. The later was surrounded with the inner space (prebulber space) that occupied by concentric perforated lamellae then enclosed in outer capsule that was consisted of flat cells (Fig.6). St. luxum contained nerve fibers (Fig. 7).

\section{The subcuites:}

It was similar to that of stratum laxum. The border between the stratum laxum of the dermis and the subcutis was formed by the lamina elastica (Fig. 5).

\section{2- One week}

\section{The skin of head region:}

There was a connection between the cornous layer, covering the dermal papilla and cornous layer of the follicular wall in some points. The Herbst corpuscle was connected to the feather follicles by an abundant elastic fibers. Dermis contained numerous blood vessels and distinct melanocytes. The follicular collar developed into three layers: inner (basiler), intermediate and outer layer. The cells of intermediate layers were rearranged into simple lines called barb ridges (Fig. 8).

\section{One month}

\section{The skin of head region:}

The vascular layer between st. superfacial and st. compactum was not clear and more thinner than that observed in hatching day
(Fig. 9). St. luxum had a great amount of adipose connective tissue (Fig. 9). St. elastica was very clear between st. luxum and subcutis (Fig. 9). The Herbst corpuscle was larger than that demonstrated in hatching day and was formed of inner pulp, concentric lamellae and outer capscule cells. (Fig. 10).

Feather follicles were more developed than those of the skin of the head region of one week age and characterized by (Fig. 11).

1- Melanocytes increased in number

2- The development appeared firstly at the middorsal part of the follicle so in cross section the barb ridges at the dorsal side were more developed than those at the ventral side of the follicle.

3- Each barb ridge was surrounded by flat cells originating from the basiler layer around the pulp to form the marginal plate also each barb ridge was divided at its peripheral portion into two barbule plates which separated by flat cells called axial plate. The inner part of barb ridges did not divide into barbule plates but formed the ramus.

4- There was no connection between st. cornum covering the dermal papilla and st. cornium af the follicular wall.

5- The pigmentation started from the most outer cells of the barb ridges to the inner 'cells. The cells of barbule plates were completely pigmented. The cells of barbule plates at the dorsal side were pigmented before those in the ventral side. The ramus began to be keratinized. The outer layer of the collar formed the follicular sheath.

6- Some follicles entered in the following step of development by disappearing of 
marginal plate between the barb ridges leaving spaces. The marginal plate disappeared at the dorsal side before the ventral side. Special type of artery was distinct in st. luxum that characterized by internal elastic membrane and abundant thick clear elastic fibers in tunica adventitia.

\section{Two month}

The epidermis was highly folded and had deep and branching invagination, forming subcutaneous diverticula. St. luxum contained a great amount of follicular muscles and fats. The follicular sheath disappeared, the barb ridges ceased and the intermediate layer of the collar formed the wall of the calamus, while the basiller layer of the collar formed the outer pulp membrane. The air space inside the calamus tube was divided by the pulp caps. The old feather was replaced by the newly formed one through the same dermal papilla. The dermal papilla, the placcode and blastema were evident in the st. luxum (Fig. 12).

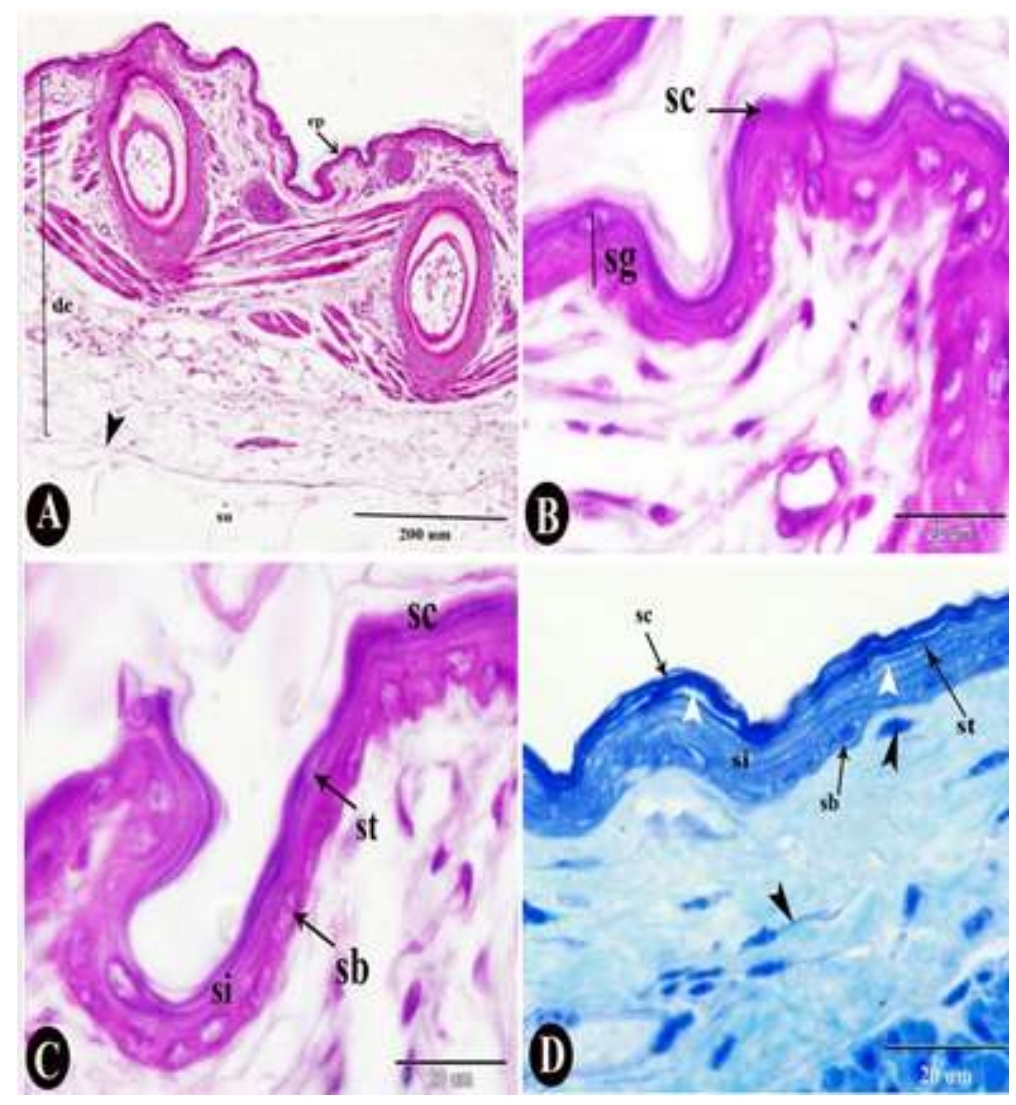

Fig. 1: The skin of the head region of sudanese duck at hatching day, showing: A- The general structure of the skin consisted of three layers; epidermis (ep), demis (de) and subcutis (su). Note, the stratum elastica (arrowhead) found between dermis and subcutis. B- Higher magnification of the epidermis showed the two layers of epidermis; stratum germinativum (sg) and stratum corneum (sc). C- Higher magnification of epidermis showing st. cornium (sc) and the layers of st. germinativum; st. basal (sb), st. intermedium (si) and st. transivitum (st). Sections A, B and C were stained by Haematoxylin and Eosin stain. D- Semithin section of the head region skin showing that the lipid droplets found in the cells of the st. basal (sb), st. intermedium (si) and increased (white arrowhead) in the st. transivitum (st) near to st. cornium (sc). Note, telocytes (black arrowheads) under the epidermis. (Toluidine blue stain). 

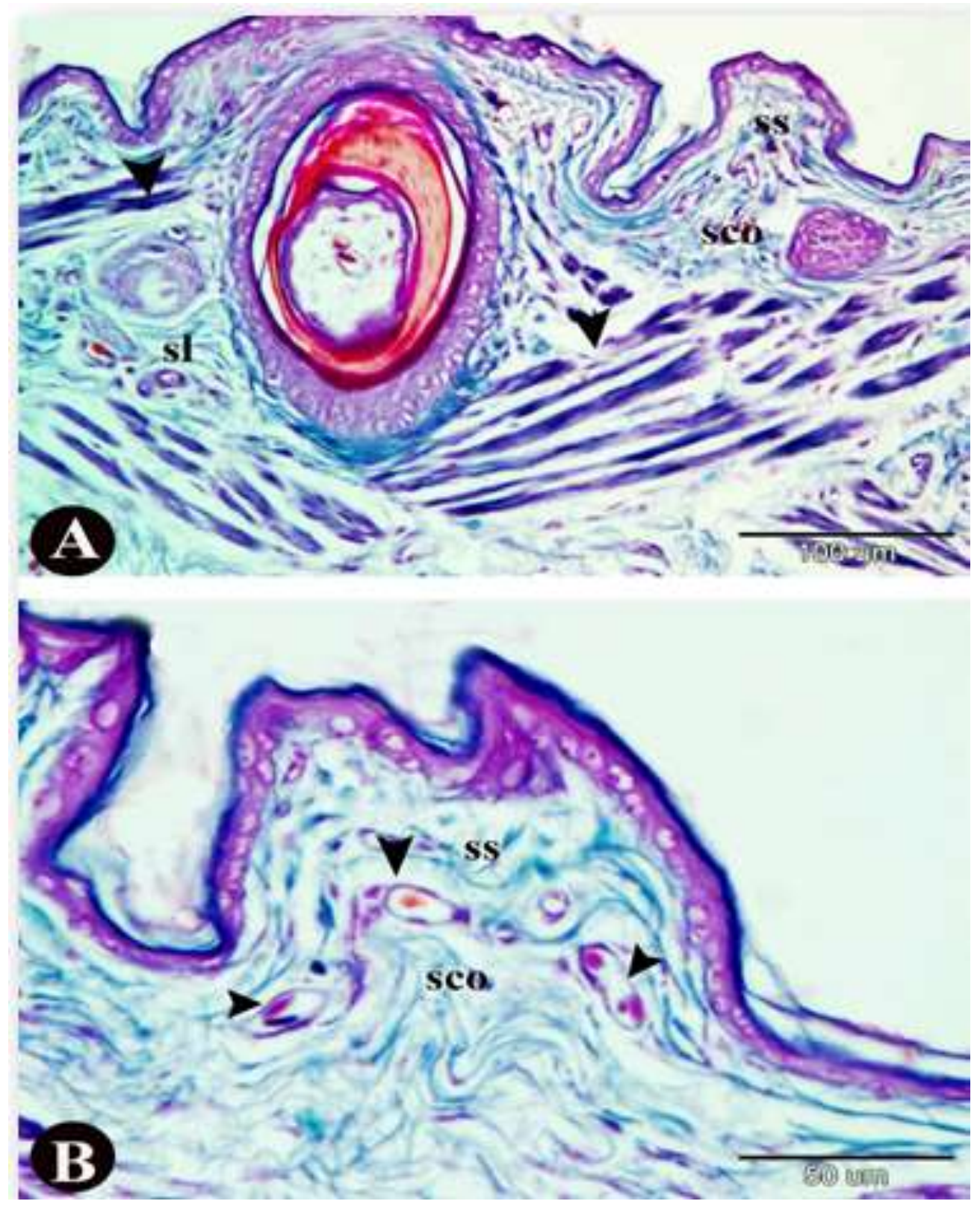

Fig. 2: The skin of the head region at hatching day showing: A- The dermis consisted of st. superfacial (ss) and st. profundum, which formed of st. compactum (sco) and st. luxum (sl). The later had follicular muscles (arrowheads). Note, the collagenous fiber (green) in the dermis of the follicular wall. B- Higher magnification revealed that both st. superfacial (ss) and st. compactum (sco) had dense collagenous connective tissue separated by vascular layer (arrowheads). (Crossmon's trichrome stain). 


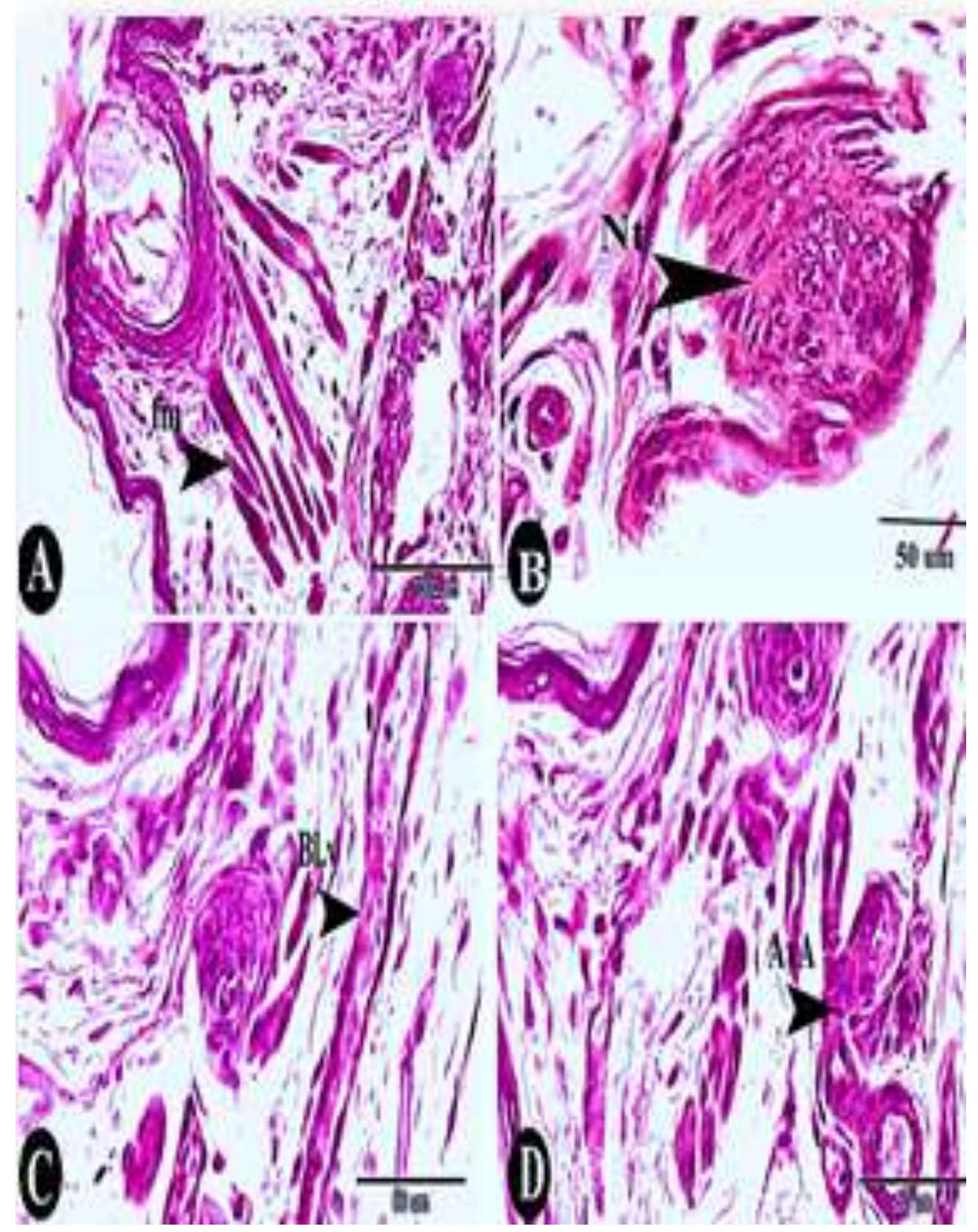

Fig. 3: The skin of the head region at hatching day showing, A- st. luxum (sl) contained follicular muscles (fm). B- st. luxum (sl) contained nerve trunk (Nt). C- st. luxum (sl) contained blood vessels (Bl.v). D- st. luxum (sl) contained arteriovenous anastomosis (AvA). (Haematoxylin and Eosin stain). 


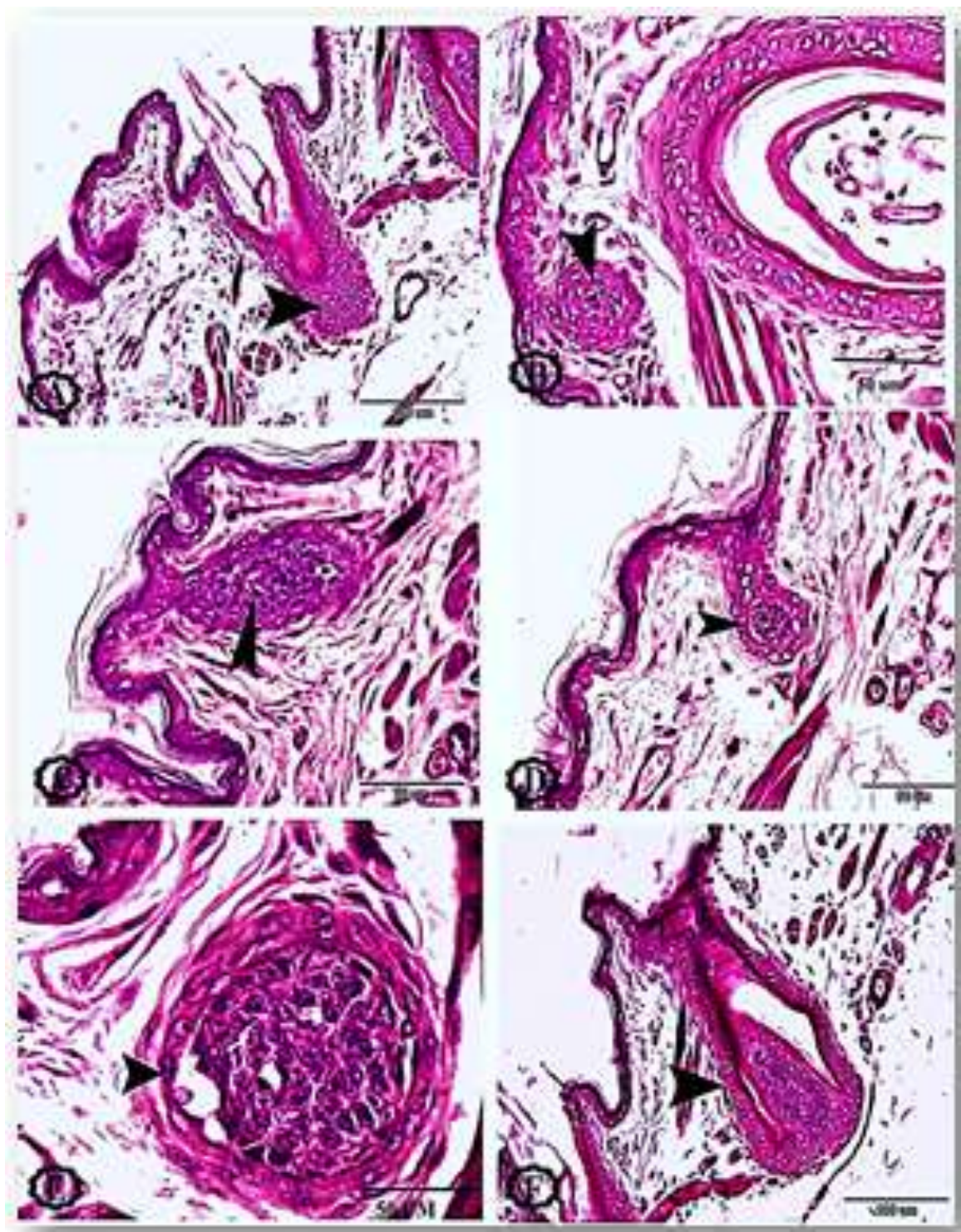

Fig. 4: The skin of the head region at hatching day showing: A- Pushing of old feather by the newly formed feather and formation of placode (arrowhead) by thickening of epidermal cells above condensed dermal cells. B- Proliferation of placode downward, forming feather bud (arrowhead). C- Elongation of feather bud forming feather bulge (arrowhead). D- The base of the bulge evaginated to envelope the condensed dermal cells forming the dermal papilla (arrowhead). E-The dermal papilla (arrowhead) was formed of specialized fibroblast, osteoblast and fat cells surrounded with epidermal layer.F- The epidermal tissue around the base of dermal papilla invaginated in the dermis forming the feather follicle wall. The epidermal layer of the papilla was continuous with the epidermis of the follicular wall and called the epidermal collar. The later with dermal papilla formed the blastema (arrowhead). (Haematoxylin and Eosin stain). 


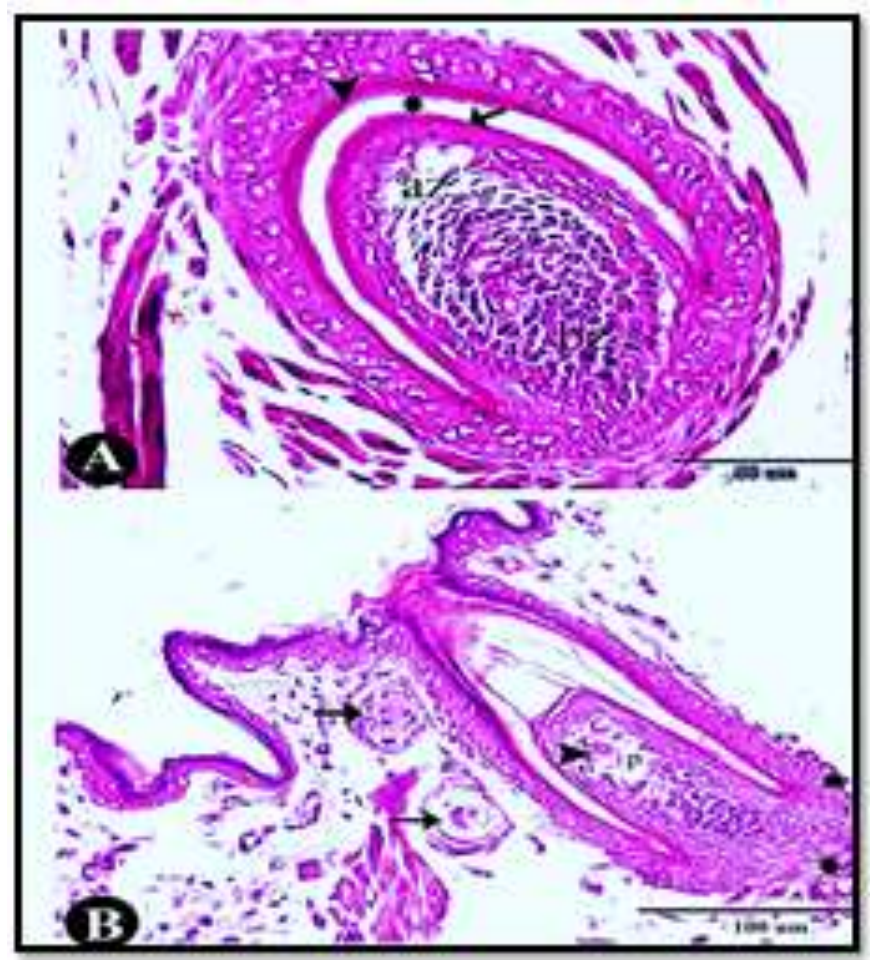

Fig. 5: A- The oblique section of the growing feather follicle in the head region skin at hatching day showing the development of blastema by elongation of dermal papilla forming apical zone (az) with flat cell and basal zone (bz) with rounded cells. The epidermis of dermal papilla formed of st. germinativum (arrow) and st. corneum (arrowhead). Note, the follicular cavity (*) between the corneal layer covering the dermal papilla and corneal layer of the follicular wall. B- The longitudinal section of the growing feather follicle in the head region skin at hatching day showing that the basal zone of the dermal papilla was continuous with the outer layer of dermis of the follicle $\left(^{*}\right)$. The apical zone of the dermal papilla formed the pulp (p), which had the central axial artery (arrowhead) in the center of the pulp. Note, two herbst corpuscles (arrows) beside the feather follicle. (Haematoxylin and Eosin stain).

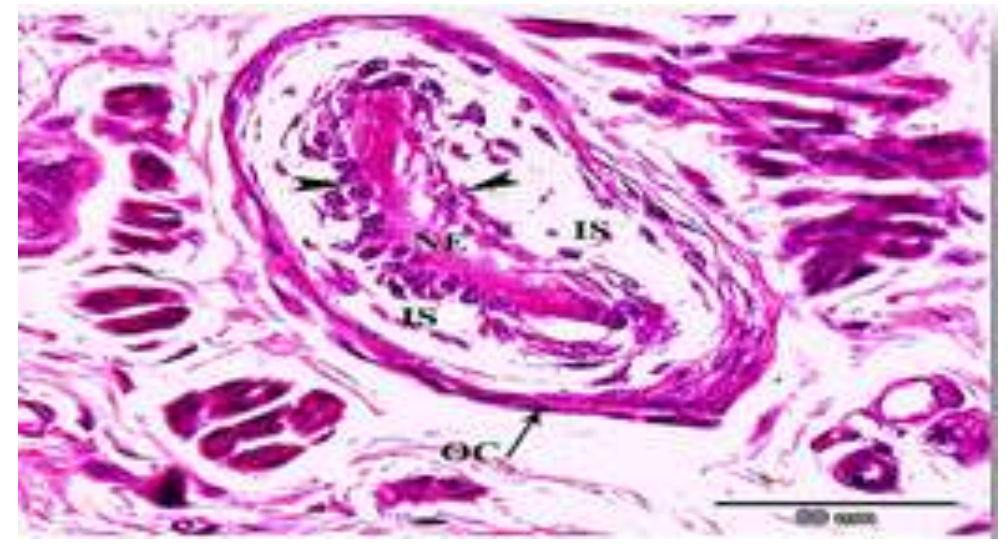

Fig. 6: Longitudinal section of the Herbst corpuscle in the skin of the head region at hatching day, showing the Herbst corpuscle, was formed of axial nerve ending (NE) surounded with inner pulp (arrowheads). The later was surrounded with inner space (IS) and enclosed by outer capsule (OC). (Haematoxylin and Eosin stain). 


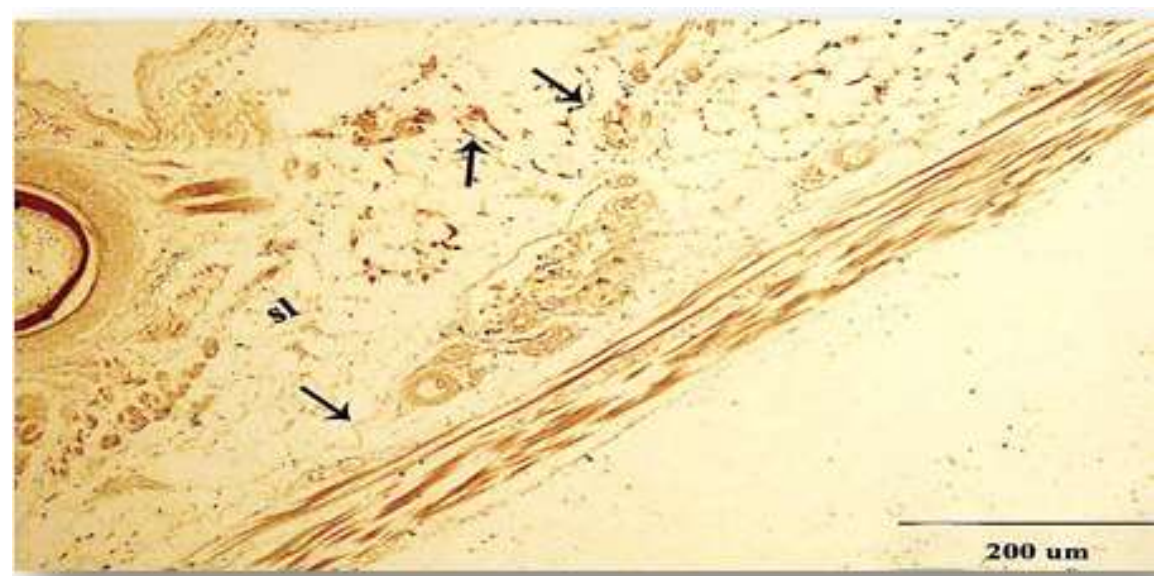

Fig. 7: The skin of the head region at hatching day, showing nerve fibers (arrows) in stratum luxum. m (Grimlius Sliver nitrate stain)

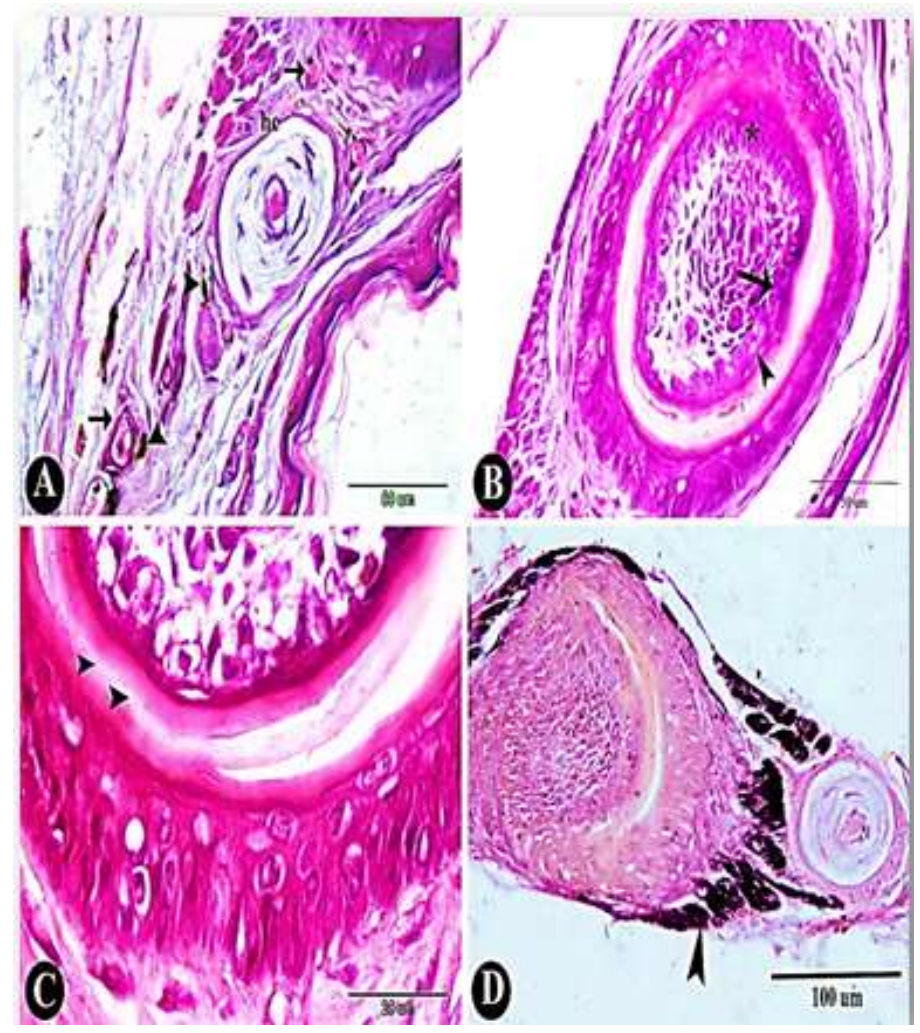

Fig. 8: The skin of the head region at one week, showing A- distinct Herbest corpuscle (hc). Dermis contained many blood vessels (arrows) and melanocytes (arrowheads) in dermis. BThe collar developed into three layers; basiler (arrow), intermediate (*) and outer layer (arrowhead). The cells of the dorsal part of intermediate layer of the collar rearranged into simple barb ridges. C- The cornous layer, covering the dermal papilla, connected with the cornous layer of the follicular wall in some points ( arrowheads). A, B and C were stained by Haematoxylin and Eosin stain. D- The Herbst corpuscle connected with the feather follicle by abundunt elastic fibers (arrowhead). (Wigert's elastica stain). 


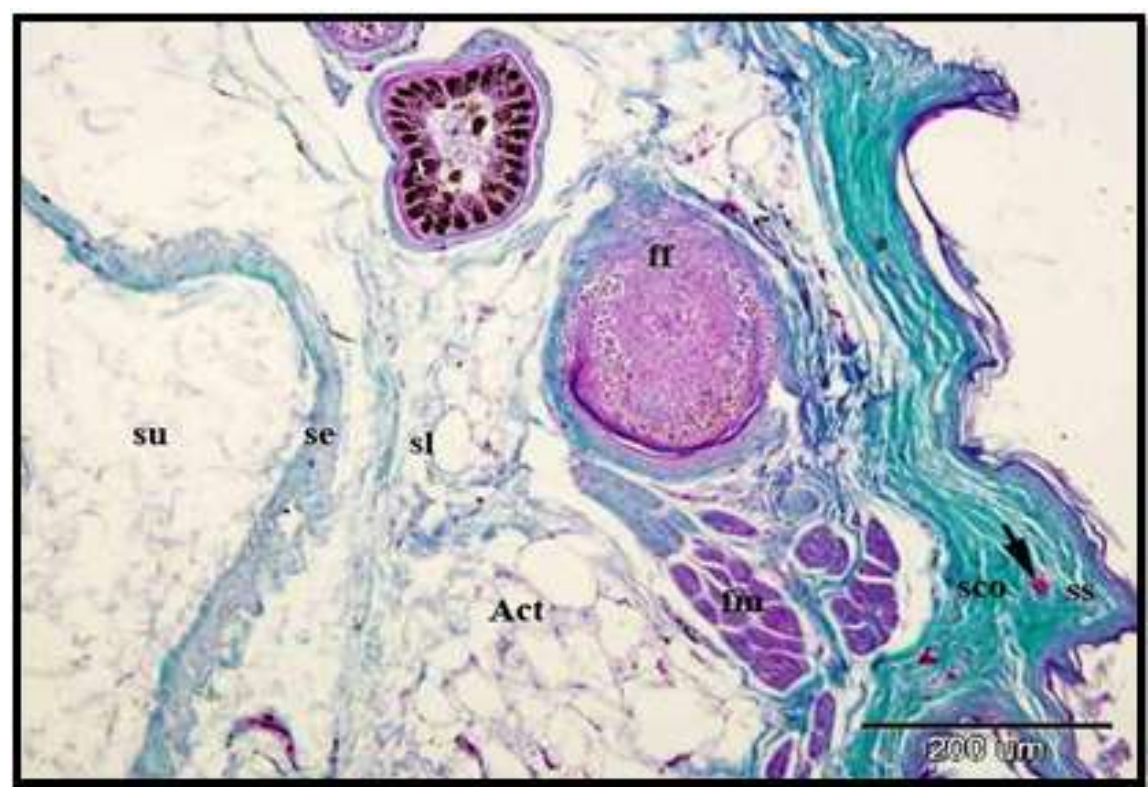

Fig. 9: The skin of the head region at one month, showing indistinct vascular layer (arrow) between st. superfacial (ss) and st. compactum (sco). St. luxum (sl) had great amount of adipose connective tissue (Act). St. elastica (se) was very clear between st.luxum and subcutis (su). follicular muscles (fm) arranged in network attached to the feather follicle (ff) by strands of collagenous connective tissue. (Crossmon's trichrome stain).

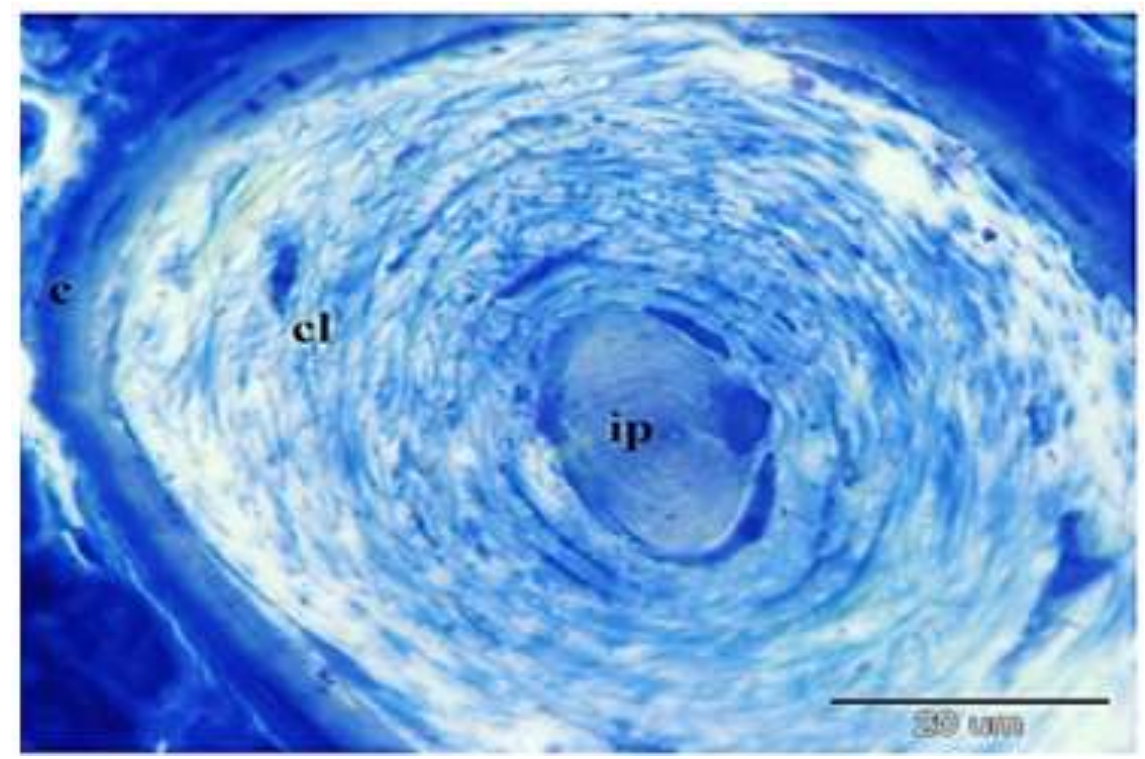

Fig. 10: Semithin section of the skin of the head at one month, showingt the Herbst corpuscle. The Herbst corpuscle formed of inner pulp (IP), concentric lamellae (cl) and capscule (c). (Toluidine blue stain) 


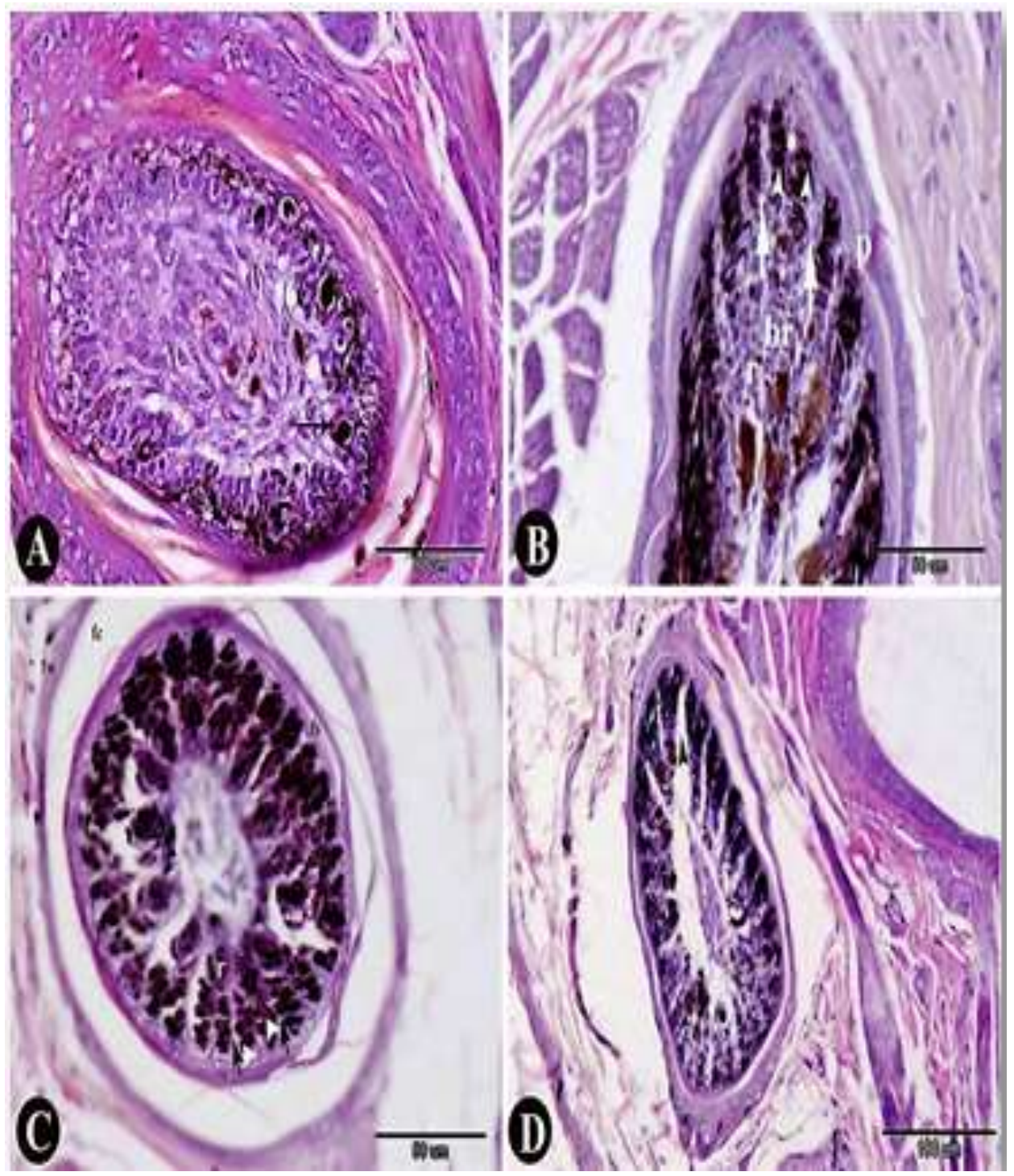

Fig. 11: A- The skin of the head region at one month age showing feather follicle with increased number of melanocytes (arrow). (Haematoxylin and Eosin stain). B- The head region skin at one month showing each barb ridge (br) surrounded by marginal plate (arrows) and divided at its peripheral portion into two barbule plates (arrowheads), which separated by axial plates (*). The inner part of barb ridges didn't divide into barbule plates but formed the ramus $(r)$. The pigmention (p) started from the most outer cells of the barb ridges then the inner cells. The ramus began to be keratinized $(\mathrm{k})$. The cells of barbule plates (arrowheads) were completely pigmented. Follicular sheath (fs) formed. Marginal plates (arrow) between some barb ridges disappeared, leaving space. Note, wide follicular cavity. (Haematoxylin and Eosin stain).C \& D- The head region skin at one month showing that the barb ridges at the dorsal side were more developed than those at the ventral side of the follicle. The cells of barbule plates at the dorsal side were pigmented before the ventral side. The marginal plate disappeared at the dorsal side (arrow head) before the ventral side. (Haematoxylin and Eosin stain). 


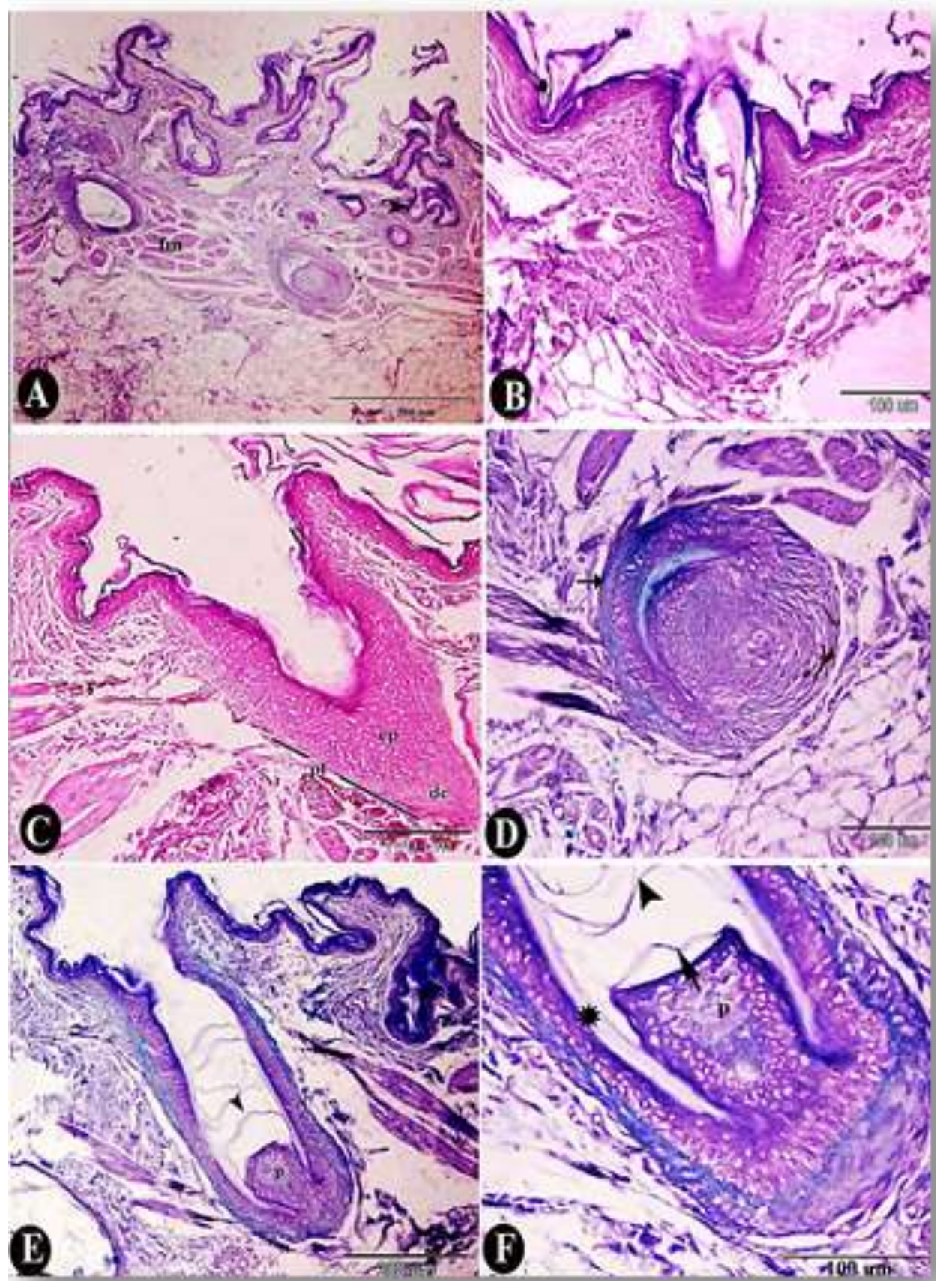

Fig. 12: A- The skin of the head region at two months, showing A- highly folded epidermis. Deep and branching invagination forming subcutaneous diverticula (arrowhead). Note, abundance of fats and follicular muscles (fm) in st. luxum. B- The old feather was pushed by the newly formed feather follicle through the same dermal papilla. C- The head skin at two months showing formation of placcode (pl) by thickning of epidermis (ep) above condensed dermal cells (dc). A, B and C were stained by Haematoxylin and Eosin stain. D- The head skin at two months showing the presence of blastema (arrow) in st. luxum. (Crossmon's trichrome stain). E \& F- The mature feather of head skin at two months showing regressed pulp (p) which, covered by the inner pulp membrane (arrow). The calamus tube was divided by the pulp caps (arrowhead). Note, the calamus wall (*). (Crossmon's trichrome stain). 


\section{DISCUSSION}

The current study was applied on the skin of the head of Sudanese duck at different ages to detect the time of maturity of the skin. The skin of head became mature at two months old age. The dermal papilla and blastema were found clearly at hatching day. The development of skin was rapid from the hatching day till one month then slowed down from one month till the maturity time.

The duck skin as any bird was marked out by some specific morphological and physiological features. It had not sweat glands while, the epidermis had lipogenic function which, was considered as characteristic feature, assuring that the skin acted as a sebaceous secretory organ (Stettenheim, 2000). The folds of epidermis increased with age. This result was similar to the result obtained by Mariana et al. (2016) in greater rhea skin. Hoath et al. (1998) stated that the stratum corneum provides a flexible tough protective covering for the body. In other vertebrates like mammals, the presence of a thicker stratum corneumwas also verified in bare areas subjeced to friction (Sokolov, 1982). Weir and Lunam (2011) found that in the emu, cellular layers and the stratum corneum were thicker in 7 day-old than in older birds.

The current study, at old ages particularly at two month age, the epidermis invaginated deeply into the dermis forming subcutaneous diverticula which didn't observed at other ages. Picasso et al. (2014) stated that the prescence of these diverticula could increase the locomotion.

Menon and Menon (2000) concluded that in all terrestrial vertebrates, the primary function of avian epidermis was to provide a permeability barrier to decrease excessive evaporative water loss and prevent death by dehydration. The functional significance of the distribution, density and morphology of epidermal lipids in avian species, including antimicrobial action, ultraviolet filtration and control cutaneous water loss has been the focus of several reviews (Menon et al., 1996). Menon (1982) suggested that some of the lipids may be utilized for the energetic of keratinization. In the current study the dermis of the skin of the Sudanese duck was divided into distinct layers, the stratum superficial, stratum compactum, stratum laxum and lamina elastic. St. superfacial and compactum were formed of dense connective tissue and st. luxum was formed of loose connective tissue, while Doaa (2014), found that the dermis of the skin of ostrich consists of superficial layer of dense irregular connective tissue which resists the multidirectional stress and a deep layer of dense regular connective tis-sue which resists the unidirectional stress.

The st. compactum was formed of collagenous c.t resembling st. superfacial and did not have fat cells. This result contrast, with those observed by Homberger and de Silva (2000), who stated that the adipose tissue of the stratum compactum and stratum laxum probably acts as a no compressible hydraulic tissue enabling the movement of feathers within the dermis.

\section{CONCLUSION}

The maturity of the skin of the head region mainly associated with the maturity of the feathers in this region. The feathers of the head were completely formed at two month old age so we can say that the skin of head region of Sudanese duck becomes mature at two month old age.

\section{REFERENCES}

Bancroft, J.D. and Layton, C. (2013): Theory \& Practice of histological techniques. 7th ed., Churchill Livingstone of El sevier, Philadelphia, 173-214.

Doaa, M.Z.A.S. El-Gendy (2014): Anatomical, light and scanning electron micro-scopical study of 
ostrich (Struthio camelus) integ-ument. J. Vet. Anat. 7, 33-54.

Elias, P.M. and Menon, G.K. (1991): Structural and lipid biochemical correlates of the epidermal permeability barrier. Advances in lipid research 24, 1-26.

El-Soukkary, F.; Mohamed, H.; Dawood, A. and Abd-El Sayed, S. (2005): Physicochemical, microbiological and lipid characteristics of duck meat. Minufiya J. Agric. Res 30, 527-548.

Foroogh, S.M.; Sara, D. and Mahsa, M. (2013): Histological Study of Ostrich Skin after Biopsy. IJVS; 8(1); Serial No: 18.

Hoath, S.B.; Visscher, M.; Heaton, C. and Neale, H. (1998): Skin science and the future of dermatology. SAGE Publications Sage CA: Los Angeles, CA.

Homberger, D.G. and De Silva, K.N. (2000): Functional microanatomy of the feather-bearing integument: Implications for the evolution of birds and avian flight. American Zoologist 40, 553-574.

Lucas, A.M. and Stettenheim, P.R. (1972): Avian Anatomy- Integument. Agricultural Handbook. Agricultural Research Services. US Department of Agriculture, Washington, DC. 362.

Mariana, B.P.; Mario, R. and Barbeito, C.G. (2016): The skin structure of greater rhea (Rheidae, Palaeognathae). Acta Zoologica 97, 302-309.

Matoltsy, A.G. (1969): Keratinization of the avian epidermis: an ultrastructural study of the newborn chick skin. Journal of ultrastructure research 29 , 438-458.

Menon, G.K.A.S.K.A. (1982): Epidermal keratinization and lipogenesis in rictus and toe web of the domestic fowl: Comparative fine structural observations. J. Anim. Morphol.
Physiol. 29.

Menon, G.; Maderson, P.; Drewes, R.; Baptista, L.; Price, L. and Elias, P. (1996): Ultrastructural organization of avian stratum corneum lipids as the basis for facultative cutaneous waterproofing. Journal of Morphology 227, 1-13.

Menon, G.K. and Menon, J. (2000): Avian epidermal lipids: functional considerations and relationship to feathering. American Zoologist 40, 540-552.

Picasso, M.B.; Mosto, M.C.; Tozzi, R.; Degrange, F.J. and Barbeito, C.G. (2014): A peculiar association: The skin and the subcutaneous diverticula of the Southern Screamer (Chauna torquata, Anseriformes). Vertebrate Zoology 64, 245-249.

Sokolov, V. (1982): Mammal Skin. Berkeley. CA: University of California Press

Spearman, R. (1966): The keratinization of epidermal scales, feathers and hairs. Biological Reviews 41, 59-95.

Stettenheim, P.R. (2000): The integumentary morphology of modern birds - an overview. American Zoologist 40, 461-477.

Teguia, A.; Ngandjou, H.M.; Defang, H. and Tchoumboue, J. (2008): Study of the live body weight and body characteristics of the African Muscovy duck (Caraina moschata). Tropical animal health and production 40, 5-10.

Weir, K. and Lunam, C. (2011): The structure and sensory innervation of the integument of ratites. In The welfare of farmed ratites, pp. 131-145. Springer.

Zaghloul, D.M. and El-Gendy, S. (2014): Anatomical, light and scanning electron micro-scopical study of ostrich (Struthio camelus) integ-ument. J. Vet. Anat. 7, 33-54. 
دراسات هستولوجية على جلد الرأس في البط السوداني في مرحلة ما بعد الفقس

مليحه أحمد هاشم ، أحد حسن ، دعاء مختار ، حنان عبد الحافظ ، ندى عبل اللاه عبل السميع عب اللاه

E-mail: vet_madeha@yahoo.com Assiut University web-site: www.aun.edu.eg

تم تطبيق الدراسة الحالية على الجلد الذى يغطى منطقة الرأس للبط السودانى cairina moschata من الفقس حتى

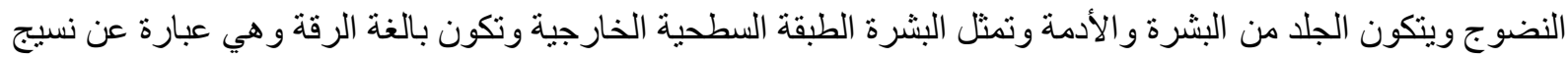

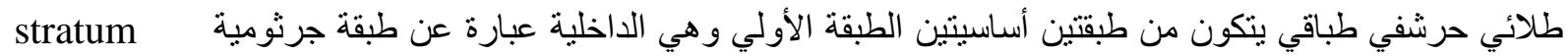

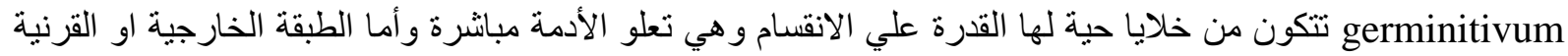
فهي عبارة عن خلابا غير حية متقرنة stratum cornium وقد قسمت الأدمة إلى الطبقة السطحية stratum superfacial و والطبقة العميقة الطبقة العيقة تتكون من طبقة رقيقة تثبه في تركيبها الطبقة السطحية وتسمى stratum compactum وطبقة سميكة وتسمى stratum luxum وكان جلا البط السوداني كباقي الطيور يتميز بوجود الريش و الذي ينمو من dermal papilla والتي تثترك مع طوق البشرة وتكون البلاستيمة وقد عثر على البلاستيمة في سن مبكرة وبخاصة في يوم الفقس ثم ينقسم طوق البشرة داخل البلاستيمة الى طبقة داخلية وخارجية

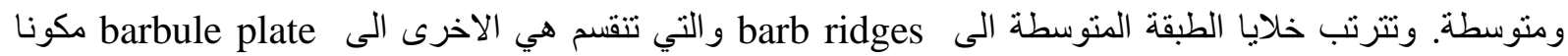
اسيلات الريشة ويرتبط نضج الجلد اساسا باكتمال نمو الريش حيث يصبح نموه مكتملا في عمر شهرين. 